\title{
GINGIVAL BIOTYPE- AN APPRAISAL IN THE ESTHETIC ZONE
}

\section{Periodontology}

Mahesh Chavda

Neeta Bhavsar

Rachana Gaonkar*

Swapna Patki

Shreeja Nair
Professor, Department of Periodontology, Government Dental College and Hospital Ahmedabad

Professor\& HOD, Department of Periodontology, Government Dental College and Hospital Ahmedabad

Post graduate student, Department of Periodontology, Government Dental College and Hospital Ahmedabad *Corresponding Author

Post graduate student, Department of Periodontology, Government Dental College and Hospital Ahmedabad

Post graduate student, Department of Periodontology, Government Dental College and Hospital Ahmedabad

\section{ABSTRACT}

The interface between the restoration and the gingival tissue seems to have a great influence on the final outcome of various treatments. Therefore, the aim of this study was to evaluate the correlation between different morphometric parameters with the thickness of buccal gingiva at the cemento- enamel junction. In 60 periodontally healthy subjects, the six maxillary anterior teeth were examined. Clinical parameters included the gingival thickness, crown width/crown length ratio $(\mathrm{CW} / \mathrm{CL})$, gingival width $(\mathrm{GW})$, papillary height and transparency of the periodontal probe through the gingival sulcus (TRAN). A positive correlation was found between the gingival thickness (GT) and the crown width/ crown length $(\mathrm{CW} / \mathrm{CL})$ ratio as well as the papillary height $(\mathrm{PH})$. A weak negative correlation was found between the transparency of probe TRAN and gingival width $(\mathrm{GW})$ with the gingival thickness $(\mathrm{GT})$. Thus, crown form (CW/CL) and papillary height are helpful indicators to determine the gingival thickness at the cemento- enamel junction. The transparency of probe method is subjective and cannot be relied upon for clinical application.

\section{KEYWORDS}

Gingival Biotype, Crown width/length, Papillary height

\section{INTRODUCTION}

Most recent studies have been focusing on the relationship of the interface between the restoration and the gingival tissue which seems to have a significant influence on the final outcome of various treatments. Knowing the gingival biotype, gingival architecture, morphologic characteristics of the teeth benefits esthetic restorations as well. Gingival biotype is the thickness of the gingiva in the faciopalatal dimension and is genetically determined in every individual $^{1}$

Patients who have undergone an immediate implant or any restorative or regenerative treatment may be prone to gingival recession or periodontal attachment loss. Proper diagnosis and necessary treatment plan alternations avoids such complications.

As regards with the gingival thickness, various studies have discussed the importance of "thick vs. thin" gingiva in restorative treatment planning. Transparency of the periodontal probe is the most commonly used method3. It is a subjective method and hence is not reliable. Thus, morphometric parameters of the anterior teeth are assessed for this purpose.

\section{MATERIALSAND METHODS}

Study design

This study was designed as a cross- sectional study comprising of 60 periodontally healthy subjects in the age group of $18-25$ years from the out- patient department of Government Dental College and Hospital, Ahmedabad. The study protocol was approved by the Ethics Committee of the Gujarat University and written consent was obtained from all subjects before clinical examination.

\section{Exclusion criteria}

- Patients with malaligned maxillary anterior teeth.

- Pateints who are orthodontically treated.

- Patients with any systemic disease (diabetes, hypertension, thyroid disorders, bleeding disorders).

- Habitual tobacco smokers or alcoholics.

\section{Clinical examination}

The six maxillary anterior teeth were examined. Clinical parameters included:

- Gingival thickness (GT): measured after delivery of topical and/or local anaesthetic, an endodontic file $(30 \mathrm{~K})$ was inserted transgingivally until contact with the tooth structure was felt (Fig. 1)

- Crown width/crown length ratio (CW/ CL): CL- between the incisal edge of the crown and the free gingival margin and CW- the distance between the proximal tooth surfaces, at the apical contact point (Fig. 4).

- Gingival width $(\mathrm{GW})$ : measured by a UNC- 15 probe from the gingival margin to the mucogingival junction after application of Lugol's iodine 2\% (Fig. 2).

- Papillary height $(\mathrm{PH})$ : measured from the top of the papilla to a line connecting the mid-facial soft tissue margin of the two adjacent teeth (Fig. 5).

- Transparency of the periodontal probe through the gingival sulcus (TRAN): insert a probe into the mid- buccal sulcus of the maxillary central incisor and you can see it through the tissue (Fig. 3).
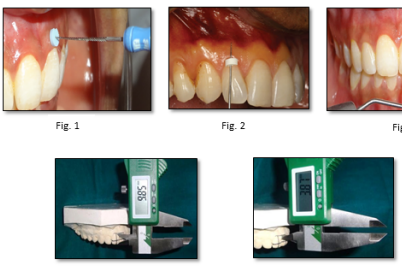

\section{RESULTS}

The study comprised of 60 subjects ( 30 males and 30 females) with a mean age of 21.5 years. Outcome values of all continuous parameters were given as mean and standard deviation (SD) as shown in Table 1. Using the Pearson correlation coefficient with the corresponding $95 \%$ confidence interval, correlations of $\mathrm{CW} / \mathrm{CL}, \mathrm{PH}$ and $\mathrm{GW}$ with the thickness of the gingiva at the cemento- enamel junction were calculated as shown in Table $2 \& 3$

Table 1 Clinical measurements

\begin{tabular}{|c|c|c|c|}
\hline & & Mean $+/-$ SD (\%) & Range \\
\hline Gingival thickness & Central incisor & $1.55+/-0.23$ & $1.32-1.78$ \\
(GT) & Lateral incisor & $1.22+/-0.21$ & $1.01-1.43$ \\
& Canine & $1.14+/-0.2$ & $0.94-1.34$ \\
\hline
\end{tabular}




\begin{tabular}{|c|c|c|c|}
\hline \hline Crown & Central incisor & $0.84+/-0.13$ & $0.71-0.97$ \\
width/crown \\
length ratio (CW/ $/$ Lateral incisor & Canine & $0.83+/-0.1$ & $0.73-0.93$ \\
CL) & & & $0.77-0.91$ \\
\hline $\begin{array}{c}\text { Gingival width } \\
\text { (GW) }\end{array}$ & Central incisor & $5+/-0.01$ & $4.99-5.01$ \\
& Lateral incisor & $5+/-0.01$ & $4.99-5.01$ \\
& Canine & $5+/-0.01$ & $4.99-5.01$ \\
\hline Papillary & CI-CI & $2.8+/-0.041$ & $2.75-2.84$ \\
height(PH) & CI-LI & $2.69+/-0.04$ & $2.65-2.73$ \\
& LI-C & $2.59+/-0.041$ & $2.54-2.63$ \\
\hline Transparency of & Central incisor & $26(43.3 \%)$ & \\
the periodontal & Lateral incisor & $35(58.3 \%)$ & \\
probe (TRAN) & Canine & $28(46.7 \%)$ & \\
\hline
\end{tabular}

Table 2

Independent Samples T-Test

\begin{tabular}{|c|c|c|c|c|c|c|}
\hline & $\mathrm{N}$ & Mean & $\begin{array}{c}\text { Std. } \\
\text { Deviation }\end{array}$ & $\begin{array}{c}\text { Std. Error } \\
\text { Mean }\end{array}$ & $\begin{array}{c}\text { Mean } \\
\text { Differen } \\
\text { ce }\end{array}$ & P Value \\
\hline $\begin{array}{c}\text { Ginigival } \\
\text { thickness(mm) }\end{array}$ & 360 & 1.22 & .23 & .012 & -2.73 & $<0.001$ \\
\hline $\begin{array}{c}\text { Papillary length } \\
(\mathrm{mm})\end{array}$ & 300 & 3.95 & .81 & .047 & & \\
\hline
\end{tabular}

\section{Table 3}

Paired T-test

\begin{tabular}{|c|c|c|c|c|c|l|}
\hline & Mean & $\mathrm{N}$ & $\begin{array}{c}\text { Std. } \\
\text { Deviatio } \\
\mathrm{n}\end{array}$ & $\begin{array}{c}\text { Std. } \\
\text { Error } \\
\text { Mean }\end{array}$ & $\begin{array}{c}\text { Mean } \\
\text { Difference }\end{array}$ & P Value \\
\cline { 1 - 5 } $\begin{array}{c}\text { Ginigival } \\
\text { thickness(mm) }\end{array}$ & 1.22 & 360 & .23 & .012 & -3.24 & $<0.001$ \\
\cline { 1 - 4 } $\begin{array}{c}\text { Gingival width } \\
(\mathrm{mm})\end{array}$ & 4.47 & 360 & .51 & .027 & & \\
\cline { 1 - 4 } $\begin{array}{c}\text { Ginigival } \\
\text { thickness(mm) }\end{array}$ & 1.22 & 360 & .23 & .012 & 0.32 & $<0.001$ \\
\cline { 1 - 4 } CW/CL & 0.91 & 360 & .11 & .006 & & \\
\hline
\end{tabular}

The relationship between TRAN and gingival thickness was evaluated with the point biserial correlation.

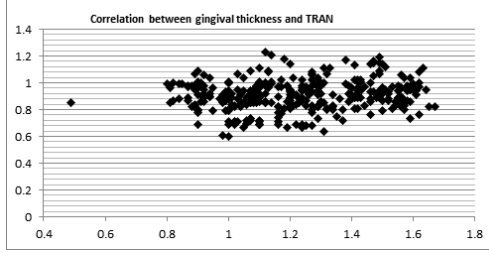

\section{DISCUSSION}

In a study by Ochsenbien and Miller2, they discussed the importance of "thick vs. thin" gingiva in restorative treatment planning. One of the most frequently used methods for identifying gingival thickness was the transparency of the periodontal probe $4,5,6,7$. However, probe transparency has not always been correlated with measurements of the gingival thickness. 4,5,8 According to a study done by Stein 2013, crown width/crown length ratio and gingival width could represent surrogate parameters to anticipate the gingival thickness at the cementoenamel junction, whereas $\mathrm{CW} / \mathrm{CL}$ might also be an indicator for alveolar bone crest thickness 11

Gingival thickness is significant in the development of mucogingival problems, in the success of periodontal surgery and also in anterior implant procedures.

Different parameters have been used to assess the gingival thickness or the so-called gingival biotype. However, there is no precise definition of how thick a thick biotype should be compared to a thin one. One of the reasons may be seen in the fact that thickness of the gingiva has been assessed at different vertical levels ${ }^{6,7,9}$.

Different methods used for assessing the gingival thickness are direct measurements 12, visual examination, probe transparency, ultrasonic devices 13 and CBCT. Each of the techniques mentioned above have their own benefits and limitations. The technique used in this study to determine the gingival biotype is by using the morphometric parameters of the esthetic zone which is more feasible, inexpensive and less time consuming.
One of the main results of this study was the positive correlation of gingival thickness at CEJ level with CW/CL ratio and papillary height. Furthermore, data from the present investigation demonstrates a weak negative correlation of the gingival thickness with gingival width and transparency of the probe.

Considering the growing attention paid to anterior aesthetics by both patients and clinicians, such findings can help enhance the knowledge of the morphologic and anatomic form of the gingiva, which can be utilized as a guide to achieve optimal soft-tissue aesthetics. A thorough understanding of the biotype form of the gingival tissue is mandatory, for a clinician so as to predict the tissue response to various pathologies as well as before treatment planning, to optimize the final outcome of the periodontal therapy.

Within the limits of the current investigation, the existence and correlation of different gingival biotypes and dentopapillary complex dimension has been confirmed. The result of the present study showed that there was highly significant correlation between gingival biotype and crown length and area of papilla. These findings can be utilized as objective guidelines for determining the biotype and response of gingiva to many dental operative procedures. But further long-term studies should be carried on with large sample size to ascertain these findings.

\section{CONCLUSION}

From this study, it can be concluded that a clear distinction between a thin and a thick gingival biotype is very difficult. Our findings suggest that crown form $(\mathrm{CW} / \mathrm{CL})$ and papillary height $(\mathrm{PH})$ are helpful indicators for the thickness of the gingiva over the cementoenamel junction. Whereas, transparency of the periodontal probe was negatively correlated with thickness of gingiva and had only minimal prognostic value for the gingival thickness. However, due to the limited sample size the results should not be generalized. Therefore, it is recommended future studies conducted may be more meaningful to verify the predictive potential of crown form and papillary height on gingival tissue thickness by using a cone beam computed tomography $(\mathrm{CBCT})$.

\section{REFERENCES}

1. Gingival Biotype and Gingival Bioform: Determining Factors for Periodontal Disease Progression and Treatment Outcome; Neha Joshi1, Manvi Chandra Agarwal2, Ellora Madan2, Shubhangi Gupta3, Aditya Law3; International Journal of Scientific Study June 2016 | Vol 4 | Issue 3

2. Ochsenbein C, Ross S. A reevaluation of osseous surgery. Dent Clin North Am 1969;13:87-102

3. Gingival biotype: The probe test utility; Madline Cuny-Houchmand1, Stéphane Renaudin1, Mustapha Leroul1, Lucie Planche2, Laurent Le Guehennec3, Assem Soueidan4, $5^{*} ;$ M. Cuny-Houchmand et al. / Open Journal of Stomatology 3 (2013) 123 127.

4. De Rouck, T., Eghbali, R., Collys, K., De Bruyn, H. \& Cosyn, J. (2009) The gingival biotype revisited: transparency of the periodontal probe through the gingival margin as a method to discriminate thin from thick gingiva. Journal of Clinical Periodontology 36 , $428-433$.

5. Cook DR, Mealey BL, Verrett RG, et al. Relationship between clinical periodontal biotype and labial plate thickness: An in vivo study. Int J Periodontics Restorative Dent 2011;31:345-354

6. Kan JY, Morimoto T, Rungcharassaeng K, Roe P, Smith DH. Gingival biotype assessment in the esthetic zone: Visual versus direct measurement. Int J Periodontics Restorative Dent 2010;30:237-243.

7. Fu, J. H., Yeh, C. Y., Chan, H. L., Tatarakis, N., Leong, D. J. \& Wang, H. L. (2010) Tissue biotype and its relation to the underlying bone morphology. Journal of Periodontology $81,569-574$

8. Eghbali, A., De Rouck, T., De Bruyn, H. \& Cosyn, J. (2009) The gingival biotype assessed by experienced and inexperienced clinicians. Journal of Clinical Periodontology 36, 958-963.

9. Olsson, M., Lindhe, J. \& Marinello, C. P. (1993). On the relationship between crown form and clinical features of the gingiva in adolescents. Journal of Clinical Periodontology 20, 570-577.

10. Olsson $\mathrm{M}$, Lindhe J. Periodontal characteristics in individuals with varying form of the upper central incisors. J Clin Periodontol 1991;18:78-82.

11. The gingival biotype: measurement of soft and hard tissue dimensions - a radiographic morphometric study. Stein JM, Lintel-Ho" ping N, Hamma"cher C, Kasaj A, Tamm M, Hanisch O. J Clin Periodontol 2013; 40: 1132-1139.

12. Greenberg, J., Laster, L. \& Listgarten, M. A. (1976) Transgingival probing as a potential estimator of alveolar bone level. Journal of Periodontology 47, 514-517.

13. Muller, H. P., Schaller, N., Eger, T. \& Heinecke, A. (2000) Thickness of masticatory mucosa. Journal of Clinical Periodontology 27, 431-436. 